\title{
SUSCEPTIBILITY OF CHICKEN INTESTINAL LACTOBACILLI TO ANTIMICROBIAL COMPOUNDS
}

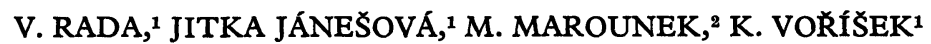

1 University of Agriculture, Department of Microbiology and Biotechnology, 16500 Prague, and ${ }^{2}$ Institute of Animal Physiology and Genetics, Czech Academy of Sciences, 10400 Prague

Received August 17, 1990

\begin{abstract}
Rada V., Jitka Jánešová, M. Marounek, K. Vořišek: Susceptibility of Chicken Intestinal Lactobacilli to Antimicrobial Compounds. Acta vet. Brno, 60, 1991 : 339-343.

Fourteen strains of lactobacilli belonging to Lactobacillus casei subsp. rhamnosus and Lactobacillus fermentum were isolated from the small intestine, caeca, intestinal mucosa and colon of chickens. The susceptibility and resistance of isolates to 20 antimicrobial agents were studied in order to identify compounds, which can influence the establishment of lactobacilli in chicken intestinal tract. The list of agents included feed additives, drugs and pentachlorphenol.

All strains tested were inhibited at the concentration of $10 \mathrm{mg} \cdot 1^{-1}$ of ionophores (monensin, lasalocid, salinomycin and narasin), tylosin, virginiamycin and penicillin. Also high concentration $\left(50 \mathrm{mg} \mathrm{.} \mathrm{l}^{-1}\right)$ of nitrovin, bacitracin and pentachlorophenol inhibited the growth. The lactobacilli were resistant to aminoglycosides (kanamycin and streptomycin), quinoxaline derivatives (olaquindox and cyadox) and avilamycin at the concentration of $10 \mathrm{mg} \cdot 1^{-1}$. All strains tested were resistant to avoparcin, nourseothricin and aureomycin at the concentration of $50 \mathrm{mg}: 1^{-1}$.
\end{abstract}

Intestinal bacteria, feed additives, antibiotics, pentachlorophenol

Lactobacilli constitute an important component of the intestinal flora in all farm animals. In chickens their numbers reach $10^{6}-10^{7}$ per $1 \mathrm{~g}$ of the small intestinal contents and $10^{\circ}$ per $1 \mathrm{~g}$ of the caecal contents (Timms 1968; Barnes 1979). Many experiments have been performed to determine effects of lactobacilli cultures as growth stimulants in domestic avian species (Mor ishita at el. 1971; Tortuero 1973; Adler and Da Massa 1980; Damron et al. 1981; Miles et al. 1981ab; Szylit and Charlet 1981; Watkins and Kratzer 1983, 1984). Stress was laid on the prevention of enteric infections and the improvement of growth rate and feed efficiency.

The establishment of the lactobacilli in the alimentary tract can be influenced by the presence of antimicrobial compounds in feed. Since very little is known about the susceptibility of avian lactobacilli to antimicrobials, the study reported herein was conducted to evaluate the effect of 16 antimicrobial agents on fourteen strains of chicken intestinal lactobacilli.

\section{Materials and Methods}

\section{Lactobacilli strains}

Fourteen lactobacilli strains were isolated from the small intestine, caeca, intestinal mucosa and colon of chickens (Table 1). Chickens used were sexed cockerels, 35 days old. One group of chickens was fed a commercial BR 2 diet based on ground wheat, barley, maize, soybean meal and a vitamin - mineral supplement. The mixture contained monensin in the amount of 100 $\mathrm{mg} . \mathrm{kg}^{-1}$. The second group was fed the same diet without monensin. Intestinal contents of cockerels were serially diluted and cultured on Rogosa agar (Oxoid). The strains displaying the general characteristics of lactobacilli were chosen for further study and identified by the criteria described in Bergey's Manual of systematic Bacteriology (Kandler and Weis 1984). One strain (No. 4) resembled Lactobacillus casei, subsp. rhamnosus. The remaining strains were identified 
Table 1

Origin of lactobacilli strains tested

\begin{tabular}{|l|l|}
\hline \multicolumn{1}{|c|}{ Strain No. } & \multicolumn{1}{c|}{ Isolated from: } \\
\hline 5,10 & Small intestine (anterior) \\
14 & Small intestine (posterior) \\
23 & Caecum \\
$32,41,4 \mathrm{R}, 6 \mathrm{R}, \mathrm{8R}, 18 \mathrm{R}$ & Colon \\
$\mathrm{A23}$ & Small intestinal mucosa (anterior) \\
141 & Small intestinal mucosa (posterior) \\
$\mathrm{A7}$ & Caecal mucosa \\
127 & Mucosa of the colon \\
\hline
\end{tabular}

as Lactobacillus fermentum. Four strains ( $4 R, 6 R, 8 R, 18 R$ ) were isolated from chickens fed a diet without monensin. The other strains were isolated from chickens fed a monensin-supplemented

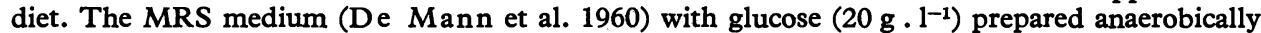
was used in this study. Cultures were routinely transferred every week or stored in agar stabs.

Susceptibility of isolates to antimicrobial feed additives

The following antimicrobial feed additives were examined: olaquindox, cyadox, nitrovin and aureomycin (Spofa, Prague, Czechoslovakia), virginiamycin (Smith Kline \& French, Genval, Belgium), monensin, narasin and avilamycin (Eli Lilly \& Co., Indianapolis, USA), lasalocid (Hoffman - LaRoche Inc., Nutley, USA), salinomycin (Hoechst, Frankfurt, Germany), bacitracin (Sigma Chemical Co., St. Louis, USA), avoparcin (Cyanamid of Great Britain, Gosport) and nourseothricin (Institute of Microbiology and Experimental Therapeutics, Jena, Germany). These compounds were dissolved in dimetylsulphoxide, ethanol, ethanol/dioxane or water and sterilized by filtration trough sterilizing asbestos filtering films (John C. Carlson, London, UK). Solutions were added to sterile media to obtain concentrations 10 and $50 \mathrm{mg} .1^{-1}$. A control contained an equivalent amount of a solvent. Cultures were incubated at $37^{\circ} \mathrm{C}$ for $40 \mathrm{~h}$. The growth was assessed as visible turbidity.

\section{Susceptibility of isolates to some antibiotics}

The same procedure was used to examine the susceptibility of lactobacilli to six common antibiotics with a therapeutic use. Kanamycin was supplied by Serva (Heidelberg, Germany), the other antibiotics (erythromycin, tylosin, streptomycin, penicillin and ampicillin) were purchased from Spofa. Erythromycin, tylosin and kanamycin were dissolved in ethanol. Streptomycin, penicillin and ampicillin were dissolved in water.

Susceptibility of isolates to pentachlorophenol

Pentachlorophenol (Fluka Chemie AG, Bush, Switzerland) was dissolved in ethanol. The experimental procedure used was the same as described above.

\section{Results and Discussion}

The lactobacilli studied were resistant to quinoxaline derivatives (olaquindox, cyadox), avoparcin, nourseothricin, avilamycin (except two strains) and aureomycin (Table 2). They were also resistant to aminoglycosides (kanamycin and streptomycin) at the concentration of $10 \mathrm{mg} \cdot 1^{-1}$ (Table 3). All strains were inhibited by ionophores (monensin, lasalocid, salinomycin and narasin), virginiamycin and except one strain by macrolides (tylosin and erythromycin). Also high concentration (50 mg . $1^{-1}$ ) of nitrovin and bacitracin inhibited the growth. No monensin-resistant lactobacilli were found in monensin-fed chickens.

Pentachlorophenol, which is currently one of the most heavily used herbicide, insecticide and fungicide, inhibited the growth of all lactobacilli strains at the concentration of $50 \mathrm{mg} \mathrm{.} 1^{-1}$, but allowed slight growth at $10 \mathrm{mg} .1^{-1}$.

There are a few studies available in the literature regarding the susceptibility of poultry lactobacilli to antimicrobial compounds. Dutta and Devriese (1981) 
Table 2

Susceptibility of chicken lactobacilli to antimicrobial feed additives

\begin{tabular}{|c|c|c|c|c|c|c|c|c|c|c|c|c|c|c|c|}
\hline \multirow{2}{*}{ Additive } & \multirow{2}{*}{$\begin{array}{l}\mathrm{Mg} \\
\cdot 1^{-1}\end{array}$} & \multicolumn{14}{|c|}{ Response $^{1}$ of strain } \\
\hline & & 5 & 10 & 14 & 23 & 32 & 41 & $4 \mathbf{R}$ & 6R & $\mathbf{8 R}$ & $18 \mathbf{R}$ & A23 & 141 & A7 & 127 \\
\hline $\begin{array}{l}\text { Olaquindox } \\
\text { Cyadox } \\
\text { Nitrovin } \\
\text { Bacitracin } \\
\text { Avilamycin }\end{array}$ & $\begin{array}{l}50 \\
50 \\
10 \\
50 \\
10 \\
50 \\
50\end{array}$ & $\begin{array}{l}\mathbf{R} \\
\mathbf{R} \\
\mathbf{R} \\
\mathbf{S} \\
\mathbf{R} \\
\mathbf{S} \\
\mathbf{R}\end{array}$ & $\begin{array}{l}\mathbf{R} \\
\mathbf{R} \\
\mathbf{R} \\
\mathbf{S} \\
\mathbf{W} \\
\mathbf{S} \\
\mathbf{R}\end{array}$ & $\begin{array}{l}\mathbf{R} \\
\mathbf{W} \\
\mathbf{R} \\
\mathbf{R} \\
\mathbf{R} \\
\mathbf{S} \\
\mathbf{R}\end{array}$ & $\begin{array}{l}\mathbf{R} \\
\mathbf{W} \\
\mathbf{R} \\
\mathbf{S} \\
\mathbf{R} \\
\mathbf{S} \\
\mathbf{R}\end{array}$ & $\begin{array}{l}\mathbf{R} \\
\mathbf{R} \\
\mathbf{R} \\
\mathbf{S} \\
\mathbf{R} \\
\mathbf{S} \\
\mathbf{R}\end{array}$ & $\begin{array}{l}\mathbf{R} \\
\mathbf{R} \\
\mathbf{R} \\
\mathbf{R} \\
\mathbf{R} \\
\mathbf{S} \\
\mathbf{S}\end{array}$ & $\begin{array}{l}\mathbb{W} \\
\mathbb{W} \\
\mathbf{R} \\
\mathbf{S} \\
\mathbf{R} \\
\mathbf{S} \\
\mathbf{R}\end{array}$ & $\begin{array}{l}\mathbf{R} \\
\mathbf{R} \\
\mathbf{S} \\
\mathbf{S} \\
\mathbf{R} \\
\mathbf{S} \\
\mathbf{R}\end{array}$ & $\begin{array}{l}\mathbf{R} \\
\mathbf{R} \\
\mathbf{R} \\
\mathbf{R} \\
\mathbf{R} \\
\mathbf{S} \\
\mathbf{R}\end{array}$ & $\begin{array}{l}\mathbf{R} \\
\mathbf{R} \\
\mathbf{R} \\
\mathbf{R} \\
\mathbf{R} \\
\mathbf{S} \\
\mathbf{S}\end{array}$ & $\begin{array}{l}\mathbf{R} \\
\mathbf{R} \\
\mathbf{R} \\
\mathbf{S} \\
\mathbf{R} \\
\mathbf{S} \\
\mathbf{R}\end{array}$ & $\begin{array}{l}\mathbf{R} \\
\mathbf{R} \\
\mathbf{R} \\
\mathbf{S} \\
\mathbf{R} \\
\mathbf{S} \\
\mathbf{R}\end{array}$ & $\begin{array}{l}\mathbf{R} \\
\mathbf{R} \\
\mathbf{R} \\
\mathbf{S} \\
\mathbf{R} \\
\mathbf{S} \\
\mathbf{R}\end{array}$ & $\begin{array}{l}\mathbf{R} \\
\mathbf{R} \\
\mathbf{R} \\
\mathbf{R} \\
\mathbf{R} \\
\mathbf{S} \\
\mathbf{R}\end{array}$ \\
\hline
\end{tabular}

1 All strains isolated were resistant to olaquindox, cyadox and avilamycin at the concentration of $10 \mathrm{mg} .1^{-1}$. All isolates were resistant to avoparcin, nourseothricin and aureomycin at the concentration of $50 \mathrm{mg} \cdot 1^{-1}$. All isolates were sensitive to monensin, lasalocid, salinomycin, narasin and virginiamycin at the concentration of $10 \mathrm{mg} \cdot 1^{-1}$. S - Susceptibility; R - Resistance; W - weak growth.

Table 3

Susceptibility of chicken lactobacilli to some antibiotics

\begin{tabular}{|c|c|c|c|c|c|c|c|c|c|c|c|c|c|}
\hline \multirow{2}{*}{ Antibiotic } & \multirow{2}{*}{$\mathrm{mg}^{\mathrm{m}}$} & \multicolumn{12}{|c|}{ Response $^{1}$ of strain } \\
\hline & & 5 & 10 & 14 & 23 & 32 & 41 & $4 R$ & $6 \mathbf{R}$ & A23 & 141 & A7 & 127 \\
\hline $\begin{array}{l}\text { Erythromycin } \\
\text { Tylosin } \\
\text { Kanamycin } \\
\text { Streptomycin } \\
\text { Ampicillin }\end{array}$ & $\begin{array}{l}10 \\
50 \\
10 \\
50 \\
10 \\
50 \\
50 \\
10 \\
50\end{array}$ & $\begin{array}{l}\mathbf{S} \\
\mathbf{S} \\
\mathbf{S} \\
\mathbf{S} \\
\mathbf{R} \\
\mathbf{R} \\
\mathbf{R} \\
\mathbf{R} \\
\mathbf{R}\end{array}$ & $\begin{array}{l}\mathbf{S} \\
\mathbf{S} \\
\mathbf{S} \\
\mathbf{S} \\
\mathbf{R} \\
\mathbf{R} \\
\mathbf{R} \\
\mathbf{R} \\
\mathbf{R}\end{array}$ & $\begin{array}{l}\mathbf{S} \\
\mathbf{S} \\
\mathbf{S} \\
\mathbf{S} \\
\mathbf{R} \\
\mathbf{R} \\
\mathbf{R} \\
\mathbf{R} \\
\mathbf{R}\end{array}$ & $\begin{array}{l}\mathbf{S} \\
\mathbf{S} \\
\mathbf{S} \\
\mathbf{S} \\
\mathbf{R} \\
\mathbf{R} \\
\mathbf{R} \\
\mathbf{R} \\
\mathbf{R}\end{array}$ & $\begin{array}{l}\mathbf{S} \\
\mathbf{S} \\
\mathbf{S} \\
\mathbf{S} \\
\mathbf{R} \\
\mathbf{R} \\
\mathbf{R} \\
\mathbf{R} \\
\mathbf{R}\end{array}$ & $\begin{array}{l}\mathbf{S} \\
\mathbf{S} \\
\mathbf{S} \\
\mathbf{S} \\
\mathbf{R} \\
\mathbf{W} \\
\mathbf{R} \\
\mathbf{S} \\
\mathbf{S}\end{array}$ & $\begin{array}{l}S \\
S \\
S \\
S \\
R \\
R \\
R \\
S \\
S\end{array}$ & $\begin{array}{l}\mathbf{R} \\
\mathbf{R} \\
\mathbf{R} \\
\mathbf{R} \\
\mathbf{R} \\
\mathbf{R} \\
\mathbf{R} \\
\mathbf{S} \\
\mathbf{S}\end{array}$ & $\begin{array}{l}\mathbf{S} \\
\mathbf{S} \\
\mathbf{S} \\
\mathbf{S} \\
\mathbf{R} \\
\mathbf{R} \\
\mathbf{S} \\
\mathbf{R} \\
\mathbf{R}\end{array}$ & $\begin{array}{l}\mathbf{S} \\
\mathbf{S} \\
\mathbf{S} \\
\mathbf{S} \\
\mathbf{R} \\
\mathbf{R} \\
\mathbf{R} \\
\mathbf{R} \\
\mathbf{R}\end{array}$ & $\begin{array}{l}\mathbf{S} \\
\mathbf{S} \\
\mathbf{S} \\
\mathbf{S} \\
\mathbf{R} \\
\mathbf{R} \\
\mathbf{S} \\
\mathbf{R} \\
\mathbf{R}\end{array}$ & $\begin{array}{l}\mathbf{S} \\
\mathbf{S} \\
\mathbf{S} \\
\mathbf{S} \\
\mathbf{W} \\
\mathbf{S} \\
\mathbf{R} \\
\mathbb{W} \\
\mathbf{S}\end{array}$ \\
\hline
\end{tabular}

1 All strains were resistant to streptomycin at the concentration of $10 \mathrm{mg} \cdot 1^{-1}$. All strains were sensitive to tylosin and penicillin at the concentration of $10 \mathrm{mg} \cdot 1^{-1}$. S - Susceptibility; R - Resistance; W - weak growth.

studied the sensitivity and resistance of 49 strains from 29 birds to eleven growth promoting agents. Most of their strains were inhibited by virginiamycin, nitrovin, carbadox and bacitracin. Results of sensitivity tests made on Gram-positive intestinal bacteria revealed that poultry lactobacilli were as a rule less sensitive than clostridia and more susceptible than enteric streptococci (Dutta and Devriese 1984).

Our findings agree with results of similar tests made on rumen lactobacilli from calves (Maroun ek et al. 1988). Also rumen lactobacilli were sensitive to ionophores and macrolides and resistant to aminoglycosides and quinoxalines. The results reported here indicate on interaction between chicken intestinal lactobacilli and some antimicrobial agents (e. g. ionophores and macrolides) which are common growth promotores, drugs and biocides. On the other hand, some antimicrobial compounds (quinoxalines, avoparcin, nourseothricin, aureomycin) may support the lactobacilli colonization as they suppress other microbes.

\section{Citlivost laktobacilů, izolovaných ze střevního traktu kuřat, vưči antimikrobiálním sloučeninám}

Z tenkého střeva, slepých střev, střevní mukózy a kolonu jsme izolovali $14 \mathrm{kmen}$ laktobacilů, radících se $\mathrm{k}$ druhưm Lactobacillus casei, Lactobacillus 
casei subsp. rhamnosus a Lactobacillus fermentum. U těchto izolátů jsme zjištovali citlivovst vưči 20 antimikrobiálním sloučeninám, ve snaze určit látky, které mohou ovlivnit osídlení střevního traktu laktobacily. Výběr antimikrobiálních látek zahrnoval krmná aditiva, některá léčiva a pentachlorfenol (běžný biocid). Růst testovaných kmenů inhibovaly ionofory (monensin, lasalocid, salinomycin, narasin), virginiamycin a penicilin. Rủst rovněž inhibovaly vyšší koncentrace (50 mg . $1^{-1}$ ) nitrovinu, bacitracinu a pentachlorfenolu. Laktobacily byly rezistentní $\mathrm{k}$ aminoglykosidům (kanamycinu a streptomycinu), chinoxalinưm (olachindoxu a cyadoxu) a avilamycinu při koncentraci $10 \mathrm{mg} .1^{-1}$. Všechny testované kmeny byly rezistentní $k$ avoparcinu, nourseothricinu a aureomycinu při koncentraci $50 \mathrm{mg} \cdot 1^{-1}$.

\section{Чүвствительность пактобациллов, изолированных из пищеварительного тракта цыплят, к антимикробным средствам}

В работе изучали чүвствительность и устойчивость лактобациллов, изолированных из пищеварительного тракта, цыплят к 20 антимикробным средствем, в которые были включены кормовые добавки, антибиотики и петахлорофенол (гербицид).

Все штаммы лактобациллов были подавлены ионофорами (моненсин, ласалоцид, салиномицин, нарасин), макролидами (тилосин и еритромицин), виргиниамицыном и пеницилином. Рост бактерий гакже подавляла высшая концентрация (50 мг.л-1) нитровина, бацитрацина и пентахлорофенола. Лактобацилли были устойчивы к хиноксапиновым дериватам (олахиндокс, циадокс), авопарцину, ноурсеотрицину, стрептомицину, канамицину, авиламицину (исключая 2 штама) и ауреомицину.

\section{References}

ADLER, H. E.-DA MASSA, A. J.: Effects of ingested lactobacilli on Salmonella infantis and Escherichia coli and on intestinal flora, pasted vents, and chick growth. Avian Dis., 24, 1980: $868-878$

ANON: The oxoid manual of culture media, ingredients and other laboratory services. 5th ed. Oxoid Ltd., Basingstoke 1982

BARNES, E. M.: The intestinal microflora of poultry and game birds during life and after storage. J. Appl. Bacteriol., 46, 1979: 407-419

DAMRON, B. L. - WILSON, H. R. -VOITLE, R. A.-HARMS, R. H.: A mixed lactobacillus culture in the diet of broad breasted large white turkey hens. Poultry Sci., 60, 1981: $1350-1351$

DE MAN, J. C.-ROGOSA, M.-SHARPE, M. E.: A medium for the cultivation of lactobacilli. J. Appl. Bacteriol., 23, 1960: 130-135

DUTTA, G. N.-DEVRIESE, L. A.: Observation on the in vitro sensitivity and resistance of Gram-positive intestinal bacteria of farm animals to growth promoting antimicrobial agents. J. Appl. Bacteriol., 56, 1984: 117-123

EL AKKAD, I. - HOBSON, P. N.: Effect of antibiotics on some rumen and intestinal bacteria. Nature, 209, 1966: 1 046-1 047

KANDLER, O.-WEISS, N.: Regular, nonsporing Gram-positive rods, p. $1208-1260$ in N. R. Krieg and J. G. Holt '(eds.): Bergey's manual of systematic bacteriology. Vol. 2. The Williams and Wilkins Co., Baltimore 1984

LENNETTE, H.-SPAULDING, E. H.-TRUANT, P. S.: Manual of Clinical Microbiology. Washington, D. C. 1974

MAROUNEK, M.-JEHLIČKOVÁ, K.-KMET, V.: Metabolism and some characteristics of lactobacilli isolated from the rumen of young calves. J. Appl. Bacteriol., 65, 1988: 43-47 
MILES, R. D.-WILSON, H. R.-ARAFA, A. S.-COLIGADO, E. C.-INGRAM, D. R.: The performance of bobwhite quail fed diets containing lactobacilli. Poultry Sci., 60, 1981a: 894-896

MILES, R. D. - WILSON, H. R. - INGRAM, D. R.: Productive performance of bobwhite quail breeders fed a diet containing Lactobacillus culture. Poultry Sci., 60, 1981b: $1581-1582$

MORISHITA, Y.-MITSUOKA, T. - KANEUCHI, C. - YAMAMOTO, S. - OGATA, M.: Specific establishment of lactobacilli in the digestive tract of germ free chickens. Jap. J. Microbiol., 15, 1971: $531-538$

SZYLIT, O.-CHARLET, G.: Energy and protein retention in holoxenic, axenic and gnotoxenic chickens monoassociated with Lactobacilluss ssp. Br. Poultry Sci., 22, 1981: 305-315

TIMMS, L.: Observations on the bacterial flora of the alimentary tract in three age groups of normal chickens. Br. Vet. J., 124, 1968: 470-477

TORTUERO, F.: Influence of the implantation of Lactobacillus acidophilus in chicks on the growth, feed conversion, malabsorption of fats syndrome and intestinal flora. Poultry Sci., 52, 1973: 197-203

WATKINS, A.-KRATZER, F. H.: Effect of oral dosing of lactobacilli strains on gut colonization and liver biotin in broiler chicks. Poultry Sci., 62, 1983: 2 088-2 094

WATKINS, B. A.-KRATZER, F. H.: Drinking water treatment with a comercial preparation of a concentrated Lactobacillus culture for broiler chickens. Poultry Sci., 63, 1984: $1671-1673$ 